\title{
Clinical evaluation of a temporary fecal containment device for non-surgical fecal diversion in perineal burns
}

\author{
Perine yanıklarında kullanılmakta olan geçici fekal diversiyon ve \\ toplama sisteminin klinik değerlendirilmesi
}

\author{
Metin KEMENT, ${ }^{1}$ Hakan Ahmet ACAR, ${ }^{2}$ İlhami Soykan BARLAS, ${ }^{2}$ Nihat AKSAKAL, ${ }^{1}$ \\ Cem GEZEN, ${ }^{1}$ Uygar DÜZCI, ${ }^{1}$ Mustafa ÖNCEL ${ }^{1}$
}

\section{BACKGROUND}

The aim of this study was to evaluate the clinical results of a temporary fecal containment device (Flexi-Seal ${ }^{\circledR}$ FMS) in our burn center.

\section{METHODS}

All patients in whom temporary fecal containment devices were applied for perineal burns between August 2008 and August 2009 in our institution were reviewed. Demographics, etiology of burns, total body surface area (TBSA) burned, intensive care unit (ICU) need, early mortality, and post-application data were obtained from a prospectively designed database. In addition, some variables were investigated as potential risks factors for fecal leakage.

\section{RESULTS}

The mean age of patients $(n=15)$ was $43.1 \pm 22.1$ years, and $66.7 \%$ of the patients were male. The mean \%TBSA burned was $40.7 \pm 16.6$. Fecal leakage was seen in 6 patients. Local infection in the perineum was observed in 6 patients, including 4 of the 6 patients with fecal leakage. The mortality rate was $33 \%$ (5 deaths). All exitus patients had $50 \%$ or more TBSA burned. Electrical burn injury was found as a significant risk factor for fecal leakage in surviving patients $(\mathrm{p}<0.05)$. Autologous split-thickness grafting was performed in 8 patients without complication. The mean duration of catheterization was $22.5 \pm 5.7$ days. Except for superficial mucosal erosion in the distal rectum in 2 cases, no complication was observed. The mean hospitalization time was $46.7 \pm 12.7$ days.

\section{CONCLUSION}

If the safety of these devices is proven in further prospective, high-volume studies, they may reduce the necessity of diverting stoma operation in burn patients.

Key Words: Fecal containment devices; perineal burns.

\section{AMAC}

Hastanemizin yanık merkezinde perine yanıklarında kullanılmakta olan geçici fekal diversiyon ve toplama sisteminin (Flexi-Seal ${ }^{\circledR}$ FMS) klinik sonuçları değerlendirildi.

\section{GEREÇ VE YÖNTEM}

Yanık merkezimizde Agustos 2008 ile Agustos 2009 arasında geçici fekal diversiyon ve toplama sistemi uygulanan tüm hastalar çalışmaya dahil edildi. Hastaların demografik bilgileri, yanık etyolojileri, yanık yüzdeleri, yoğun bakım ihtiyaçları, erken mortalite ve uygulama sonrası klinik bilgileri prospektif olarak hazırlanan bir veritabanında toplandı. Bunların yanında bu sistemin uygulandığı hastalarda fekal kaçak riskini arttırabilecek çeşitli faktörler de incelendi.

\section{BULGULAR}

Çalışmaya 15 hasta (10 erkek, 5 kadın; ortalama yaş $43,1 \pm 22,1$ ) dahil edildi. Ortalama yanık yüzdesi 40,7 $\pm 16,6$ idi. Fekal kaçak 6 hastada görüldü. Perinede lokal enfeksiyon gelişen 6 hastanın 4'ü fekal kaçaklı hastalardı. Elektrik yanığı sistemden fekal kaçak için bir risk faktörü olarak bulundu $(\mathrm{p}<0,05)$. Çalışmamızda sistemin uygulandığ 5 hasta kaybedildi. Kaybedilen hastaların tümünde yanık yüzdesi $\geq 50$ idi. Otolog split greft uygulanan toplam 8 hastada ciddi komplikasyon görülmedi. Sistemin ortalama uygulama süresi 22,5 $\pm 5,7$ gündü ve 2 hastada yüzeyel rektal mukozal erozyon dışında sisteme bağlı komplikasyon görülmedi. Çalışmamızda sistemin uygulama ihtiyacı 29 günü aşan 1 hastaya kolostomi uygulandı. Hastaların ortalama yatış süresi ise $46,7 \pm 12,7$ gündü.

\section{SONUÇ}

Geçici fekal diversiyon ve toplama sistemlerinin güvenilirliği yapılacak daha güçlü ve prospektif çalışmalarla kanıtlanabilirse perine yanıklarında saptırıcı stoma gereksinimini azaltabilirler.

Anahtar Sözcükler: Fekal diversiyon; perine yanıları.
Departments of ${ }^{1}$ General Surgery, ${ }^{2}$ Burn Center, Kartal Education and Research Hospital, Istanbul, Turkey.
Dr. Lütfü Kırdar Kartal Eğitim ve Araștırma Hastanesi, ${ }^{1}$ Genel Cerrahi Kliniği, ${ }^{2}$ Yanık Merkezi, İstanbul. 
The perineum is not a common region for burn injuries. Alghanem et al. ${ }^{[1]}$ reported the incidence of perineal burns as about $1.2 \%$. However, burns to the perineum that involve the pubic area and structures lying between the thighs, including the external genitalia and peri-anal area, require special attention. ${ }^{[2]}$ In the acute phase, management of perineal burns can be challenging on its own. The area has a high bacterial load comprising fecal organisms from the anus, which may lead to serious generalized infections by way of the damaged skin or urogenital tract. Fecal contamination may also increase the risk of flap or graft loss. Thus, the most important issue for perineal burns is diverting feces from the burned area to avoid serious infective complications.

Temporary fecal containment devices have been developed to manage bedridden, immobilized and incontinent patients as an alternative to traditional methods such as pads, diapers, fecal pouches, and rectal tubes. Temporary fecal containment devices can also be used for diverting feces from the burned area. Theoretically, these devices may diminish both the risk of skin breakdown and spread of infection by protecting the patients' wounds from feces. These devices may also be an alternative to diverting colostomy. The aim of this study was to evaluate the early clinical results of these devices in our burn center.

\section{MATERIALS AND METHODS}

All patients in whom temporary fecal containment devices were applied for perineal (including gluteus and upper thigh) burns between August 2008 and August 2009 in our institution were reviewed in this study. Demographics (age, gender), etiology of burns, total body surface area (TBSA) burned, intensive care unit (ICU) need, early mortality, and post-application data (fecal leakage, infections, complications, graft operations, duration of application, and hospitalization time) were obtained from a prospectively designed da-

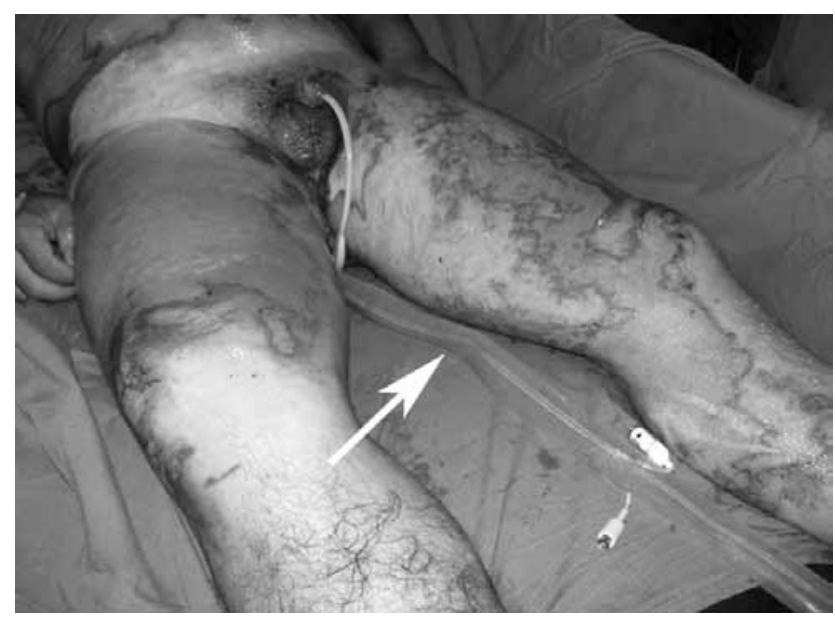

Fig. 1. A patient with Flexi-Seal ${ }^{\circledR}$ FMS. tabase. In addition, some variables (age, gender, etiology of burns, \%TBSA burned, and ICU need) were investigated as potential risks factors for fecal leakage in these patients.

We used Flexi-Seal ${ }^{\circledR}$ fecal management system (FMS) as the temporary fecal containment device. Flexi-Seal ${ }^{\circledR}$ FMS consists of a soft silicone catheter, a syringe and a collection bag. At one end, the soft silicone catheter has a retention balloon that is inserted into the rectum. At the opposite end, the catheter has a connector for attaching the collection bag. On the first admission day of the patients, the catheters were inserted into the rectum by a resident under sedation or general anesthesia after a digital rectal examination to detect any fecal impaction or anorectal abnormality. The retention balloon was inflated with $45 \mathrm{ml}$ water and placed carefully into the pelvic floor (Fig. 1). Lactulose (Duphalac ${ }^{\circledR} 670 \mathrm{mg} / 300 \mathrm{ml}$ syrup, Solvay S.A.) was added to the enteral nutrition of patients to increase fluidity of the feces. Additionally, catheters were irrigated 3 times daily with $100 \mathrm{cc}$ water to avoid obstruction of the catheter.

The catheter was removed whenever a satisfactory wound or graft healing was confirmed by a burn surgeon. The length of catheterization did not exceed 29 days based on the manufacturer's recommendation. A digital rectal examination was performed on all patients to detect any mucosal injury after removal of the catheter.

All statistical analyses were performed with SPSS for Windows 17.0. In all sample analyses, means were compared with unpaired Student's t-test and frequency distributions with Fisher's exact probability test or chi-squared test. $\mathrm{p}=0.05$ (two-sided) was considered as the limit of significance.

\section{RESULTS}

A total of 351 patients were admitted to our burn center between August 2008 and August 2009. Use of temporary fecal containment device was decided for $15(4.3 \%)$ patients.

The mean age of the patients was $43.1 \pm 22.1$ years (range: $18-76$ ), and $66.7 \%$ of the patients were male. The mean \%TBSA burned was $40.7 \pm 16.6$ (range: 20 $70 \%$ ). All patients had burns involving one or more of the perineum, gluteus or upper thigh. Causes of burns were flame in $8(53.3 \%)$, electricity in $5(33.3 \%)$ and hot water in $2(13.3 \%)$ patients.

The devices were placed intra-rectally on the first admission day in all patients. Minimal fecal leakage was seen in $6(40 \%)$ patients. Local infection in the perineum confirmed by tissue culture was observed in $6(40 \%)$ patients, including 4 of the 6 patients with fecal leakage. Two patients had no local infection in 
Table 1. Characteristics and demographics of deceased patients

\begin{tabular}{lccccccc}
\hline No & Age/Gender & TBSA (\%) & Cause of burn & ICU need & Fecal leakage/ Time & Cause of death & Time of death (day) \\
\hline 1 & $18 / \mathrm{M}$ & 60 & Electricity & Yes & No & Septicemia & 7 \\
2 & $49 / \mathrm{F}$ & 50 & Flame & Yes & Yes/ 2nd day & Septicemia & 6 \\
3 & $72 / \mathrm{F}$ & 65 & Flame & Yes & No & Multiple Organ Failure & 5 \\
4 & $34 / \mathrm{M}$ & 70 & Flame & Yes & No & Multiple Organ Failure & 2 \\
5 & $20 / \mathrm{M}$ & 60 & Electricity & Yes & No & Septicemia & 14 \\
\hline
\end{tabular}

ICU: Intensive care unit; TBSA: Total body surface area.

spite of fecal leakage. Positive blood cultures were detected in $3(20 \%)$ patients, all of whom $(n=3)$ died from multiple organ failure caused by septicemia. Besides these 3 patients, another 2 patients who had no sign of infection died from multiple organ failure in the early stage of hospitalization. All exitus patients had $50 \%$ or more TBSA burned. These 5 deceased patients $(\mathrm{n}=5,33.3 \%)$ were excluded from further analysis because of the short follow-up period (Table 1).

Autologous split-thickness grafting was performed in 8 patients for the management of perineal wounds. The operations were performed within 7 days of admission in 6 patients; however, the operations in 2 patients were postponed to the 12th and 14th days of admission due to local infections. No significant graft loss requiring re-grafting was observed in our grafted patients. Electrical burn injury was found as a significant risk factor for fecal leakage in the surviving patients $(\mathrm{p}<0.05)$ (Table 2).

The mean duration of catheterization was $22.5 \pm 5.7$ days (range: $12-29)$ in the surviving patients $(n=10)$. Except for superficial mucosal erosion in the distal rectum in 2 patients, no complication due to the device was observed in our cases. Colostomy was required in 1 patient because of wound healing delay (exceeding 29 days). The mean hospitalization time was $46.7 \pm 12.7$ days (range: $26-64$ ).

\section{DISCUSSION}

In our burn center, the incidence of perineal-involvement burns was $4.3 \%$ during the study period. All patients with perineal burns also had extensive burn injuries to the trunk and/or lower limbs $(40.7 \%$ mean TBSA burned), and the mortality was 33\% (5 patients) in our study. All exitus patients had $50 \%$ or more TBSA burned. Peck et al. ${ }^{[3]}$ reported a $28.2 \%$ mortality rate in perineal-involvement burns.

Temporary diverting colostomy is a conventional method to avoid contamination of the burned perineal area by feces. Theoretically, diverting colostomy decreases fecal contamination and aids wound healing in perineal burns, but there are only two studies including a limited number and age groups of patients about diverting colostomies in perineal burns. Quarmby et al. firstly reported 13 pediatric cases with two minimal complications (two stomal prolapse), and then $\mathrm{Na}$ kazawa et al. reported five elderly cases without any complications..$^{[4,5]}$ Although these two limited studies did not report any significant complication, large volume studies on the safety and efficacy of colostomies have demonstrated that some serious complications requiring reoperation, such as necrosis, parastomal hernia and stenosis might arise following colostomies. ${ }^{[6,7]}$ Furthermore, closure of colostomy carries some serious complication risks (e.g. anastomotic leakage, bowel injury and even mortality) $\cdot{ }^{[8]}$ Additionally, it

Table 2. Characteristics and demographics of surviving patients

\begin{tabular}{|c|c|c|c|c|c|c|c|c|c|c|}
\hline No & $\begin{array}{c}\text { Age/ } \\
\text { Gender }\end{array}$ & $\begin{array}{c}\text { TBSA } \\
\text { burned }(\%)\end{array}$ & $\begin{array}{l}\text { Cause of } \\
\text { burn }\end{array}$ & $\begin{array}{l}\text { ICU } \\
\text { need }\end{array}$ & $\begin{array}{l}\text { Graft to } \\
\text { perineum }\end{array}$ & $\begin{array}{c}\text { Fecal leakage/ } \\
\text { Time }\end{array}$ & $\begin{array}{c}\text { Local } \\
\text { infection }\end{array}$ & $\begin{array}{l}\text { Catheter } \\
\text { duration }\end{array}$ & Comp. & $\begin{array}{c}\text { Hospitalization } \\
\text { time }\end{array}$ \\
\hline 1 & $76 / \mathrm{M}$ & 30 & Electricity & Yes & Yes & Yes / 4th day & No & 21 & No & 52 \\
\hline 2 & 71/M & 40 & Flame & Yes & Yes & Yes / 5th day & Yes & 29 & Yes & 58 \\
\hline 3 & $25 / \mathrm{M}$ & 30 & Electricity & No & Yes & Yes / 4th day & Yes & 21 & No & 64 \\
\hline 4 & $23 / \mathrm{M}$ & 25 & Flame & No & No & No & No & 14 & No & 40 \\
\hline 5 & $74 / \mathrm{F}$ & 20 & Flame & No & Yes & Yes / 4th day & No & 25 & Yes & 30 \\
\hline 6 & $21 / \mathrm{M}$ & 40 & Flame & Yes & Yes & No & No & 29 & No & 62 \\
\hline 7 & 19/M & 30 & Flame & No & Yes & No & No & 24 & No & 45 \\
\hline 8 & $52 / \mathrm{F}$ & 20 & Hot Water & No & No & No & No & 12 & No & 26 \\
\hline 9 & $48 / \mathrm{M}$ & 30 & Hot Water & Yes & Yes & No & No & 25 & No & 44 \\
\hline 10 & $44 / \mathrm{M}$ & 40 & Electricity & Yes & Yes & Yes / 3rd day & Yes & 25 & No & 46 \\
\hline
\end{tabular}

Comp.: Complications; ICU: Intensive care unit; TBSA: Total body surface area. 
may not be possible to find an adequate area for colostomy, especially in patients with extensive abdominal burns. Another problem, particularly in patients with extensive burns, is that colostomy may decrease the potential skin surface area for grafting. Perhaps one of the most important issues about diverting colostomies is their effectiveness in preventing sepsis in extensive burns, in which bacterial translocation is more important than direct contamination for the development of sepsis. Thus, well-designed and adequately powered studies are still needed to determine the role of diverting colostomies in the management of perineal burns.

To our knowledge, the present study is the largest series on temporary fecal containment devices in the management of perineal burns. Keshava et al. ${ }^{[9]}$ reported 20 patients (13 severe perineal excoriations and only 7 perineal burns). They used the Zassi Bowel Management System (Zassi BMS) for fecal containment. There are some differences between the FlexiSeal FMS and Zassi BMS. Flexi-Seal FMS consists of a soft silicone catheter tube assembly, syringe and collection bags. The catheter is inserted into the rectum and the retention balloon is inflated with $45 \mathrm{cc}$ of water. Zassi BMS consists of a silicone catheter with a collapse-resistant annulus, a low-pressure retention cuff and collection bags. After the catheter is inserted, the retention cuff is inflated with 35 to $40 \mathrm{cc}$ of water. Flow through the catheter can be stopped by using an intraluminal balloon. Economic impact of these two commercial bowel catheter systems was compared in a multicenter, observational study including 146 bedridden patients, and Zassi BMS was found more costeffective than Flexi-Seal FMS. ${ }^{[10]}$ Although Bordes et al. ${ }^{[11]}$ reported 8 burned patients in whom they used both types of catheters (Zassi BMS in 6 patients and Flexi-Seal in 2 patients), they could not draw a conclusion on the differences in safety or effectiveness between these two models of catheters due to the low number of patients.

Fecal leakage was seen in $6(40 \%)$ patients in our study. Local infection developed in 4 of these 6 patients and 1 of them, who had 50\% TBSA burn, died on the 6th day of hospitalization due to septicemia. If the 5 exitus patients were excluded because of the short follow-up period, the fecal leakage rate would increase to $50 \%$ in our study. Bordes et al. ${ }^{[11]}$ reported fecal leakage in 6 of 8 patients $(75 \%)$ without any mortality. Padmanabhan et al. ${ }^{[12]}$ reported daily assessment results in a prospective, single-arm, multi-center study with 42 diarrheic and incontinent patients, and they reported some degree of fecal leakage in 140 of 198 daily assessments (71\%). In our opinion, the high risk of fecal leakage is still the most bothersome problem for temporary fecal containment devices, even if its importance on mortality was not demonstrated in either our study or that of Bordes et al.
Temporary fecal containment devices may prevent the complications of diverting colostomies. However, it should not be forgotten that any catheterization adjacent to the mucosa may result in serious ischemic ulcerative complications, including perforation. Moreover, the risk of ischemic ulcerative complications may be higher than others in burned patients because of the reduction in peripheral blood flow. We placed the catheters on the first admission day and we did not exceed 29 days in catheter application, as recommended by the manufacturer. The mean duration of catheterization was $22.5 \pm 5.7$ days (range: $12-29$ ) in our study. We had to perform colostomy in one patient with delayed wound healing ( $>29$ days). Keshava et al. ${ }^{[9]}$ reported that they had used the Zassi BMS in one patient for 59 days without any mucosal injury. They exceeded 29 days only in this patient; the mean duration of catheterization was 21 days in their study, which was similar to our study (22.5 days). On the other hand, Bordes et al. ${ }^{[11]}$ reported that they had exceeded 29 days in 6 of 8 patients with 4 complications, including reversible anal atony in 2 patients, bowel occlusion in 1 patient and anal ulceration in 1 patient. The mean duration of catheterization was 35 days (range: 6-70) in their study. Even though we did not exceed 29 days in catheterization, we also observed superficial mucosal erosions in 2 patients. In our opinion, the catheterization should not be prolonged, and colostomy should be performed in the case of wound healing delays.

In the present study, we also investigated the potential risk factors for fecal leakage in these patients, and only electrical burn injury was found as a significant risk factor for fecal leakage. This is probably due to the more harmful effect of electrical burn on sphincter muscles of the anus than other etiologies of burns. However, it is obvious that our results were obtained from a very limited number of patients and should be supported by more powered, prospective trials that include manometric measurements.

In conclusion, temporary fecal containment devices aim to protect patients' wounds from fecal contamination by diverting the feces. If the safety of these devices is proven in further studies, they may reduce the necessity of diverting stoma operation in burn patients.

\section{REFERENCES}

1. Alghanem AA, McCauley RL, Robson MC, Rutan RL, Herndon DN. Management of pediatric perineal and genital burns: twenty-year review. J Burn Care Rehabil 1990;11:308-11.

2. Huang T. Management of burns injuries of the perineum. In: Herdorn D, editor. Burn care. Philadelphia: Saunders Elsevier Inc; 2007. p. 749-58.

3. Peck MD, Boileau MA, Grube BJ, Heimbach DM. The management of burns to the perineum and genitals. J Burn Care Rehabil 1990;11:54-6.

4. Quarmby CJ, Millar AJ, Rode H. The use of diverting colos- 
tomies in paediatric peri-anal burns. Burns 1999;25:645-50.

5. Nakazawa H, Ito H, Morioka K, Kikuchi Y, Honda T, Isago T. The use of temporary diverting colostomy to manage elderly individuals with extensive perineal burns. Burns. 2002;28:595-9.

6. Park JJ, Del Pino A, Orsay CP, Nelson RL, Pearl RK, Cintron JR, et al. Stoma complications: the Cook County Hospital experience. Dis Colon Rectum 1999;42:1575-80.

7. Ciğgdem MK, Onen A, Duran H, Oztürk H, Otçu S. The mechanical complications of colostomy in infants and children: analysis of 473 cases of a single center. Pediatr Surg Int 2006;22:671-6.

8. Pokorny H, Herkner H, Jakesz R, Herbst F. Mortality and complications after stoma closure. Arch Surg 2005;140:956-60.
9. Keshava A, Renwick A, Stewart P, Pilley A. A nonsurgical means of fecal diversion: the Zassi Bowel Management System. Dis Colon Rectum 2007;50:1017-22.

10. Kowal-Vem A, Poulakidas S, Barnett B, Conway D, Culver $\mathrm{D}$, Ferrari M, et al. Fecal containment in bedridden patients: economic impact of 2 commercial bowel catheter systems. Am J Crit Care 2009;18:2-15.

11. Bordes J, Goutorbe P, Asencio Y, Meaudre E, Dantzer E. A non-surgical device for faecal diversion in the management of perineal burns. Burns 2008;34:840-4.

12. Padmanabhan A, Stern M, Wishin J, Mangino M, Richey K, DeSane M; Flexi-Seal Clinical Trial Investigators Group. Clinical evaluation of a flexible fecal incontinence management system. Am J Crit Care 2007;16:384-93. 